\title{
Globalization and International Tax Competition: Empirical Evidence Based on Effective Tax Rates
}

\author{
Lucas Bretschger \\ WIF-Institute of Economic Research \\ Frank Hettich \\ Infraserv GmbH \& Co Höchst KG
}

\begin{abstract}
Previous work showing a positive impact of globalization on capital tax revenue as a percent of GDP claims to contradict theoretical results that tax competition pressures governments to reduce taxes on highly mobile assets. However, the observed relationship is not necessarily incompatible with the predictions of tax competition literature, as the internationalization of markets also affects the capital tax base. Measuring taxes by effective tax rates instead of tax revenue for a panel of 12 OECD countries in the period 1967-96, we find that globalization has a negative impact on capital taxes, which is exactly what the theory predicts.
\end{abstract}

- JEL Classifications: H7, H87, C23

- Key words: Tax competition, Empirical evidence, Panel data, OECD countries

\section{Introduction}

Are taxes on corporate capital increasing or decreasing with rising globalization? Economic theory predicts that tax competition forces governments to reduce taxes on more mobile assets such as corporate capital. On the other hand, recent empirical contributions, especially Garrett (1995), Quinn (1997) and Swank (1998), find a positive relationship between capital tax revenue as a percent of GDP and

\footnotetext{
*Corresponding address: Lucas Bretschger, WIF - Institute of Economic Research, ETH Zentrum, 8092 Zurich, Switzerland, Tel: +41-1-632-21-92, Fax: +41-1-632-13-62, E-mail: lbretschger@ethz.ch. Frank Hettich, Infraserv GmbH \& Co Höchst KG, 65926 Frankfurt, Germany.

(C2005-Center for International Economics, Sejong Institution, All Rights Reserved.
} 
international trade and/or financial exposure. However, since capital tax revenue as a percent of GDP equals capital tax rates times the capital base divided by total income, the observed relationship is not necessarily incompatible with greater openness reducing the tax rate. If, at the same time, openness raises the capital output/ratio and, especially, if it does so by lower tax rates, a positive impact of globalization on tax revenue can be expected according to theory.

This paper analyzes the different effects of globalization on the corporate capital tax burden. Specifically, it clarifies the role of the measurement of variables, in particular the tax rates, and emphasizes that this issue is crucial for the debate. Moreover, it motivates the set of control variables in the estimation using a microeconomic foundation. As a result, it turns out that tax competition theory is able to predict the tax behavior of the governments, while many past empirical contributions cannot be interpreted as contradicting the theory. The outcome in the present paper is related to Rodrik (1997) who finds that openness has a negative effect on capital taxes and a positive effect on labor taxes. However, his results are not robust when one adds a qualitative dummy variable for international exchange rate restrictions and an interaction term of this dummy with the proxy for openness. The paper also refers to Garrett (2000) who reports new results using effective tax rates, as we strongly suggest. Most importantly, he admits that the past claim of positive effects of openness on capital taxation cannot be sustained. We are able to show why this is the case.

An important insight of our contribution is that capital tax revenue should on no account be related to GDP, which merits a clear accentuation and sufficient explanation in literature. In addition, empirical estimations should preferably rely on an accurate set of explanatory variables which are derived from theory. Compared to the present study, Garrett (2000) uses different exogenous variables, which partly reflects the fact that his estimations include several taxes as well as government expenditures, all using identical estimation equations. For capital tax rates, Garrett obtains a significant impact of the lagged tax rates, the growth rate and the rate of unemployment. While the first two findings are corroborated by our results, the suggested negative effect of unemployment on capital taxes lacks adequate theoretical foundation. On the other hand, our variable for government orientation is well-established in the literature and proves to be successful in all estimations. While Garrett's study remains inconclusive regarding tax policy we obtain a sufficiently clear result in favor of theoretical predictions. Concerning the use of dummy variables, our study seeks to introduce additional dummies after a 
specific explanation, while other papers include them right from the beginning. A further difference between Garrett and the present contribution lies in the period under investigation (Garrett: 1973-93; this paper: 1967-96).

In the following sections, we first develop a small tax competition model, based on economic theory. Then, we motivate the use of effective capital tax rates and different measures for globalization. Finally, we test the model with panel data for 12 OECD countries and show the difference between the results for effective capital tax rates and capital tax revenue in percent of GDP.

\section{Theoretical Background}

Let us first present the theoretical predictions of the simplest tax competition model where only capital is taxed; for a more detailed exposition see Zodrow and Mieszkowski (1986) ${ }^{1}$. The government is assumed to choose the optimal capital tax rate and to determine public services subject to its budget constraint:

$$
G=\tau \cdot K
$$

where $G$ denotes the supply of public services, $\tau$ the proportional capital tax, and $K$ the domestic capital stock. The government chooses the tax rate $\tau$ such that marginal benefits from public services $M B$ equal marginal costs of tax raising $M C$ that is:

$$
M B=M C .
$$

To determine the components of $M C$, we totally differentiate (1) to obtain

$$
d G=d \tau \cdot K+\tau \cdot d K
$$

The first term on the rhs of (3) gives the marginal individual cost of taxation. A higher tax decreases households' after-tax income, which means lower private consumption possibilities. The second term corresponds to the impact of capital taxation on the tax base. In a closed and static economy, this term is zero because $K$ is constant. In an open economy, however, any increase in $\tau$ causes a capital

\footnotetext{
'This basic model has been extended in several ways, including large countries and additional tax instruments (see Bucovetsky 1991, Wilson 1991 and Bucovetsky and Wilson 1991, respectively) without changing the fundamental results.
} 
outflow to other economies. The lower the cost for capital holders to shift capital abroad, the larger this outflow, which is a fiscal externality, becomes. Transaction costs of capital mobility tend to fall with increasing openness of the economy. Hence, marginal costs of taxation rise with globalization. As a consequence, international exposure forces national governments to reduce the capital tax burden so that equation (2) can be fulfilled. The size of $M B$ is determined by individual utility of public services and the ideological preferences of the government and (possibly) parliament.

In fact, the government is not a unitary actor, it consists of a group of politicians. In addition, the assumption of welfare-maximizing behavior disregards the incentives of governments and political parties, which maximize probabilities of election. Most importantly, government behavior is determined by ideological preferences, as Cusack (1997) shows in his empirical study. Because the political sector has an important impact on capital taxes, we introduce political considerations through a variable for the political centre of gravity on a right-leftscale. The marginal benefit $(M B)$ of an increase of $G$ still equals marginal cost $(M C)$ of taxation, as in equation (2), but $M B$ depends on government preferences. It is normally postulated that conservative governments favor a lower level of public activities than leftist governments. Moreover, it is commonly assumed that leftist governments favor redistribution and high capital taxation, while conservative governments favor the unhindered functioning of the market system and hence low capital taxation.

To summarize, once we control for the preferences of the government, the more open the economy is, the lower capital taxes are predicted to be. As usual, this is a ceteris paribus result. When using the model in empirical work, additional factors affecting $K$ also have to be considered. Notably, many dynamic trade models predict a positive impact of international trade on the return of capital because of production efficiency effects. ${ }^{2}$ In the same way, technological progress raises capital return. In addition, lower capital taxes lead to higher private return on capital. All these effects stimulate incentives for domestic capital investments and/ or capital inflow, that is they have a positive impact on $K$. Depending on the form of the aggregate production function, the capital/output ratio may change as a consequence of globalization and/or technical progress. Note that in this case, the

\footnotetext{
${ }^{2}$ See Baldwin (1992), who argues in terms of one-sector models. In multi-sector models, the prediction is at least valid for capital-abundant economies, which applies to OECD countries; for the case of trade in dynamic R\&D-models, see Bretschger (1997).
} 
relationship between the income share of capital tax revenue and globalization is not determined by the tax competition model. Provided that openness has a strong positive effect on the capital/output ratio, globalization might well have a positive impact on capital tax revenue as a share of GDP, while the impact on capital tax rates is still negative.

To test the results of the simple tax competition model, we have to regress openness on the tax rate, holding constant the preferences of the government and growth due to exogenous technical progress. We can then compare this finding with the result for capital tax revenue.

\section{Measuring Taxes and Openness}

The measurement of both capital tax burden and openness has to be carefully studied. To illustrate the different points in detail, we refer to the study of Quinn (1997) and then introduce our own procedure. Quinn's cross-section study covers four issues: the impact of international financial liberalization on long-term growth, on government expenditures, on income inequality and on corporate taxation. To test the different effects on capital taxes, Quinn uses data for 38 countries and builds average values for the period 1974-91. He introduces income growth per capita, investment as a percentage of GDP and the sum of imports and exports as a percentage of GDP as exogenous variables. As endogenous variables, Quinn uses different proxies for corporate taxation: corporate tax revenues as a percentage of $\mathrm{GDP}^{3}$, of individual taxation or of total taxation. As noted in the previous section, these proxies are not appropriate in our view. Specifically, the proxy "corporate tax revenues as a percentage of GDP" suffers from three major insufficiencies. First, the proxy is not the relevant tax variable of tax competition theory. This is a major problem, as in this context we are particularly interested in analyzing the government's corporate tax burden decisions with nations becoming increasingly integrated in world markets. The government can determine the tax rate, but certainly not the GDP (denominator of the proxy). Second, the size of the operating surplus of firms and the number of corporate enterprises as a distinct impact factor of tax revenues are completely disregarded. The positive correlation between the proxy "corporate tax revenues as a percentage of GDP" and the proxy of capital market integration, found by Quinn, may be caused solely by a rise in the corporate

${ }^{3}$ This measure is also used by Garrett (1995). 
tax base. For 12 industrialized countries, the average surplus of corporate enterprises - which can be seen as the real tax base of corporate taxation - as a percentage of GDP has risen from 8.21 per cent in 1980 to 9.82 per cent in 1996. This corresponds to an increase of 19.63 per cent, which means that the operating surplus has grown faster than GDP. Since this development coincides with ongoing capital market integration, the measured positive relations might solely reflect a rise in the tax base, which is out of the control of the government. Third, when we observe the strategic behavior of multinational firms, another problem becomes evident. These enterprises have the opportunity to reduce their tax burden by shifting the surplus to low-tax countries by means of transfer prices. Imagine, for instance, that multinational firms shift their surplus to Luxembourg for that reason. In this case, the proxy "corporate taxation as a percentage of individual taxation" will increase, thus incorrectly indicating Luxembourg to be a high-tax country. In fact, the opposite would be correct. To conclude, the proxies used for corporate taxes are not suited to depict the appropriate corporate taxation decisions of governments, which lie at the heart of tax competition theory.

To avoid the weaknesses of these proxies, we use effective average tax rates calculated with the methodology proposed in the seminal paper of Mendoza, Razin and Tesar (1994). Tax rates are obtained through division of total tax revenues from corporate taxation by the operating surplus of corporate enterprises. Only capital taxes from the corporate sector are included. Applying this procedure, we acknowledge the fact that the effective tax burden is determined not only by the statutory tax rate but also by the legal tax base. This is important as national tax bases differ due to complex national differences in tax-credits, tax-exemptions and tax-deductions for identical operating surpluses. Taxes are measured as average rates which is the appropriate indicator for firms when taking international location decisions. Figure 1 shows the different development of corporate taxation as a percentage of GDP and the effective average corporate tax. The unweighted effective corporate tax rate (corptax) for all countries sharply increases in the late sixties and early seventies to more than 41 per cent and then constantly decreases to a level below 34 per cent in the period 92-96. However, the series for corporate tax revenues as a percentage of GDP (corpshare) used by Quinn and Garrett shows a different development.

The measurement of globalization is also difficult. The common variable used in the cited empirical studies, called open below, is calculated as the sum of imports and exports as a percentage of GDP. ${ }^{4}$ The assumption is that economies which are 
Figure 1. Measures of corporate taxation

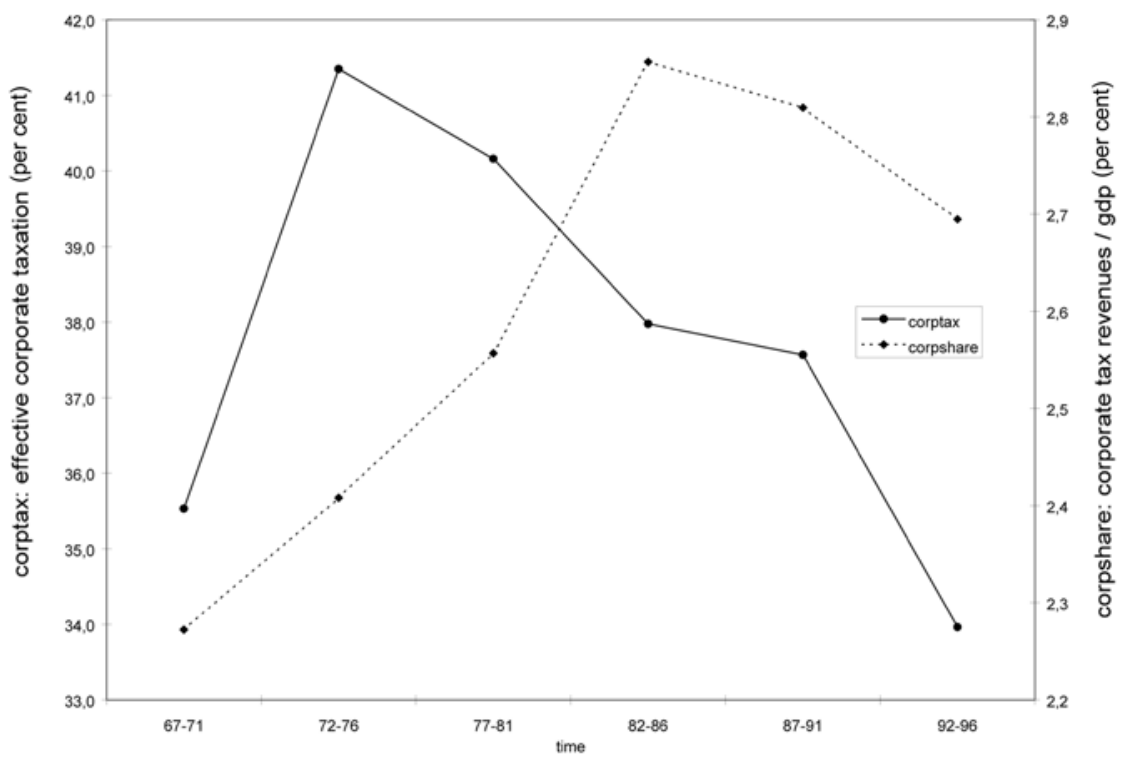

more exposed to trade and are thus more internationally orientated tend to be economies with higher capital mobility. Note that every goods trade across borders is accompanied by an international financial transaction. Furthermore, most studies also use a qualitative measure for financial market liberalization and globalization. The variable openness is a qualitative index, ranging from most closed (0) to most open (14); it is constructed by analyzing inward and outward capital and current account restrictions and by regarding international legal agreements that constrain a nation's ability to restrict exchange and capital flows. ${ }^{5}$ A further proxy for capital market liberalization is interest rate differentials. Because open interest rate differentials depend on expectations and the risk aversion of investors, covered interest rate differentials calculated with forward foreign-exchange rates have been used for empirical work. However, the problem of how the forward exchange rate is influenced by expectations remains as exchange rate models normally assume trading firms to hedge completely, whereas all speculators operate in the forward market. Another possibility is the use of "investment abroad as a percentage of GDP". Here, it should be noted that an adequate measure of openness has to refer to the potential to move capital rather than the actual flows of foreign direct

\footnotetext{
${ }^{4}$ The data are described in the appendix.

${ }^{5}$ For a more detailed description of this qualitative index, see Quinn (1997).
} 
investments. For instance, in equilibrium of a dynamic trade model, no foreign direct investments will take place although the capital market may be fully integrated. Furthermore, governments can influence international capital flows by changing required reserves of bank's deposit liabilities; for this reason, Dooley and Chinn (1997) conclude that covered interest parity conditions and the scale of investment abroad are inappropriate to assess the openness of financial systems.

To summarize, there is no ideal variable to measure globalization. Quantitative trade measures are reliable in the sense that they are based on generally accepted statistics but are only a proxy for capital market transactions. Qualitative variables for capital market liberalization depend on the way they are constructed and normally do not have much variation for highly developed economies. Finally, quantitative proxies for capital markets are influenced either by expectations, required bank's reserves or the emergence of disequilibria. Following the studies we refer to in this note, we rely on the globalization measures open and openness to have both a quantitative and qualitative measure of globalization. By introducing these variables our estimations become highly comparable to the cited literature; this allows us to emphasise the different results between the use of effective tax rates and tax revenue as a percentage of GDP.

\section{Evidence from Panel Data for OECD Countries}

Before presenting our results, we briefly specify the variables used in our estimations. ${ }^{6}$ corptax denotes effective tax rates whereas corpshare stands for capital tax revenue as a percent of GDP. As noted, globalization is captured by the variables open and openness. The variable growth corresponds to technological progress of the theoretical model. Progress is assumed to be exogenous as in the neo-classical growth model and parts of newer growth theory, see e.g. Jones (1995). We use the growth rate of GDP measured in PPP-US-dollars. With the variable gov, we test whether ideological preferences of the government influence tax policy. gov is the sum of variables measuring the center of political gravity for electorate, legislature and cabinet, ranging from 3 (far left) to 15 (far right). ${ }^{7}$ It should be noted that similar variables are used by the cited studies, so that our results are comparable to literature.

\footnotetext{
${ }^{6}$ For further details, the appendix.

${ }^{7}$ For further details, see Cusack (1997).
} 
We collected annual data from 1967 to 1996 for 12 OECD countries. ${ }^{8}$ For estimation, we adopt the Beck/Katz specification ${ }^{9}$ of panel corrected standard errors by using the corresponding option in the Stata software package. To show that results depend on the chosen measure for capital taxes, we use either corptax or corpshare as dependent variable for otherwise identical equations and data. In all estimations, we include the lagged endogenous variable because of policy inertia and control for the economy's growth rate and the ideological preferences of the government. In addition, we check the influence of the qualitative indicator openness. Following some of the cited literature, we also introduce country dummies in two additional equations. Once a model is appropriately specified, the use of these dummies is by no means mandatory. But it can be argued that it is difficult to capture all relevant factors for countries that are very different like the countries that are not in the European Union. Thus one equation is introduced with a dummy for each non EU-country (column 3). The last equation (column 4) includes all country dummies except the one for the UK, which is the reference country in this case.

Table 1 summarizes the results. On the left hand side (columns 1a - 4a), our measure corptax is the endogenous variable. Most importantly, globalization or the degree of integration of countries in the world economy measured by open has a significantly negative impact on corporate taxes throughout the estimations. This result is robust with respect to changes in specification and sample, except for the case where all country dummies are included (column 4a). There the sign is still negative but the standard error becomes somewhat too big. Including dummies for countries that really differ from a priori reasoning as in equation $3 \mathrm{a}$, the result is fully in accordance with expectations and highly significant. The same holds true for most other combination of dummies that are used to reflect major institutional differences between countries. We conclude that we are able to support the theory of tax competition with empirical evidence. The impact of growth on taxation is negative, as predicted, and significant. The variable gov for the center of political gravity shows the predicted and significant result throughout. However, the variable openness is not successful in this context, although multicollinearity with open can be excluded. Most probably this is a consequence of the lack of variation

\footnotetext{
${ }^{8}$ Belgium, Canada, France, Germany, Italy, Japan, the Netherlands, Norway, Sweden. Switzerland, the United Kingdom, and the United States. Unfortunately, for the first years data are not available for all the countries considered.
}

${ }^{9}$ Beck and Katz (1995). 
Table 1. Results of estimations

\begin{tabular}{|c|c|c|c|c|c|c|c|c|}
\hline & \multicolumn{8}{|c|}{ endogenous variable } \\
\hline & \multicolumn{4}{|c|}{ corptax } & \multicolumn{4}{|c|}{ corpshare } \\
\hline & $1 \mathrm{a}$ & $2 a$ & $3 a$ & $4 a$ & $1 b$ & $2 b$ & $3 b$ & $4 \mathrm{~b}$ \\
\hline const & $\begin{array}{c}25.72 * * * \\
(5.81)\end{array}$ & $\begin{array}{c}28.71 * * * \\
(6.24)\end{array}$ & $\begin{array}{c}28.52 * * * \\
(4.46)\end{array}$ & $\begin{array}{c}34.11 * * * \\
(7.67)\end{array}$ & $\begin{array}{c}0.21 \\
(0.29)\end{array}$ & $\begin{array}{c}0.32 \\
(0.32)\end{array}$ & $\begin{array}{c}0.18 \\
(0.34)\end{array}$ & $\begin{array}{l}0.007 \\
(0.42)\end{array}$ \\
\hline $\operatorname{corptax}(-1)$ & $\begin{array}{c}0.78^{* * *} \\
(0.03)\end{array}$ & $\begin{array}{c}0.78^{* * *} \\
(0.03)\end{array}$ & $\begin{array}{c}0.74 * * * \\
(0.04)\end{array}$ & $\begin{array}{c}0.65^{* * *} \\
(0.04)\end{array}$ & & & & \\
\hline corpshare(-1) & & & & & $\begin{array}{c}0.90 * * * \\
(0.02)\end{array}$ & $\begin{array}{c}0.90^{* * *} \\
(0.02)\end{array}$ & $\begin{array}{c}0.82 * * * \\
(0.03)\end{array}$ & $\begin{array}{c}0.74 * * * \\
(0.04)\end{array}$ \\
\hline open & $\begin{array}{c}-4.57 * * \\
(1.79)\end{array}$ & $\begin{array}{c}-4.39 * * \\
(1.79)\end{array}$ & $\begin{array}{c}-5.89 * * * \\
(2.08)\end{array}$ & $\begin{array}{l}-10.10 \\
(6.67)\end{array}$ & $\begin{array}{c}0.10 \\
(0.08)\end{array}$ & $\begin{array}{c}0.11 \\
(0.08)\end{array}$ & $\begin{array}{l}0.21^{*} \\
(0.10)\end{array}$ & $\begin{array}{l}0.98^{* *} \\
(0.393)\end{array}$ \\
\hline openness & & $\begin{array}{l}-0.33 \\
(0.26)\end{array}$ & $\begin{array}{l}-0.09 \\
(0.29)\end{array}$ & $\begin{array}{c}0.18 \\
(0.34)\end{array}$ & & $\begin{array}{l}-0.012 \\
(0.02)\end{array}$ & $\begin{array}{l}0.007 \\
(0.02)\end{array}$ & $\begin{array}{c}0.01 \\
(0.02)\end{array}$ \\
\hline growth & $\begin{array}{c}-0.46^{* * *} \\
(0.21)\end{array}$ & $\begin{array}{c}-0.54 * * \\
(0.22)\end{array}$ & $\begin{array}{l}-0.61^{* *} \\
(0.23)\end{array}$ & $\begin{array}{c}-0.65^{* *} \\
(0.22)\end{array}$ & $\begin{array}{c}0.05^{* * *} \\
(0.01)\end{array}$ & $\begin{array}{c}0.05^{* * *} \\
(0.01)\end{array}$ & $\begin{array}{c}0.04 * * * \\
(0.01)\end{array}$ & $\begin{array}{c}0.05 * * * \\
(0.01)\end{array}$ \\
\hline gov & $\begin{array}{c}-1.48^{* * *} \\
(0.49)\end{array}$ & $\begin{array}{c}-1.34 * * * \\
(0.50)\end{array}$ & $\begin{array}{c}-1.27 * * * \\
(0.56)\end{array}$ & $\begin{array}{c}-1.30^{* *} \\
(0.65)\end{array}$ & $\begin{array}{l}-0.01 \\
(0.03)\end{array}$ & $\begin{array}{l}-0.004 \\
(0.03)\end{array}$ & $\begin{array}{l}-0.001 \\
(0.03)\end{array}$ & $\begin{array}{c}0.01 \\
(0.04)\end{array}$ \\
\hline Canada & & & $\begin{array}{c}-3.59^{* *} \\
(1.76)\end{array}$ & $\begin{array}{c}-7.88^{* * *} \\
(2.21)\end{array}$ & & & $\begin{array}{c}0.06 \\
(0.10)\end{array}$ & $\begin{array}{l}-0.01 \\
(0.12)\end{array}$ \\
\hline Japan & & & $\begin{array}{l}1.26 \\
(2.09)\end{array}$ & $\begin{array}{l}-1.60 \\
(2.82)\end{array}$ & & & $\begin{array}{c}0.51^{* * *} \\
(0.16)\end{array}$ & $\begin{array}{c}0.73^{* * *} \\
(0.19)\end{array}$ \\
\hline Norway & & & $\begin{array}{l}-1.57 \\
(2.07)\end{array}$ & $\begin{array}{l}-3.22 \\
(2.94)\end{array}$ & & & $\begin{array}{c}0.41 * * * \\
(0.14)\end{array}$ & $\begin{array}{c}0.20 \\
(0.19)\end{array}$ \\
\hline Switzerland & & & $\begin{array}{l}-2.48 \\
(3.41)\end{array}$ & $\begin{array}{l}-5.23 \\
(3.64)\end{array}$ & & & $\begin{array}{l}-0.06 \\
(0.21)\end{array}$ & $\begin{array}{c}-0.43^{* *} \\
(0.22)\end{array}$ \\
\hline USA & & & $\begin{array}{l}-1.91^{*} \\
(2.10)\end{array}$ & $\begin{array}{c}-9.46^{* * *} \\
(3.28)\end{array}$ & & & $\begin{array}{c}0.06 \\
(0.12)\end{array}$ & $\begin{array}{c}0.12 \\
(0.19)\end{array}$ \\
\hline Belgium & & & & $\begin{array}{c}1.43 \\
(5.19)\end{array}$ & & & & $\begin{array}{l}-0.82 \\
(0.31)\end{array}$ \\
\hline France & & & & $\begin{array}{c}-6.60^{* * *} \\
(2.20)\end{array}$ & & & & $\begin{array}{l}-0.25^{*} \\
(0.13)\end{array}$ \\
\hline Germany & & & & $\begin{array}{l}-3.19 \\
(2.18)\end{array}$ & & & & $\begin{array}{c}-0.40^{* * * *} \\
(0.11)\end{array}$ \\
\hline Italy & & & & $\begin{array}{c}3.48 \\
(2.62)\end{array}$ & & & & $\begin{array}{l}0.27 * \\
(0.15)\end{array}$ \\
\hline Netherlands & & & & $\begin{array}{l}-5.32 \\
(4.12)\end{array}$ & & & & $\begin{array}{c}-0.49^{* *} \\
(0.24)\end{array}$ \\
\hline Sweden & & & & $\begin{array}{l}-2.20 \\
(2.44)\end{array}$ & & & & $\begin{array}{c}-0.36^{* *} \\
(0.14)\end{array}$ \\
\hline Nr. obs: & 297 & 297 & 297 & 297 & 297 & 297 & 297 & 297 \\
\hline Number & 12 & 12 & 12 & 12 & 12 & 12 & 12 & 12 \\
\hline$\chi^{2}$ & 775.73 & 781.75 & 813.66 & 892.27 & 1773.90 & 1777.91 & 1879.40 & 2087.00 \\
\hline
\end{tabular}

Standard errors in parentheses;

$*, * *, * * *$ for significance at the $90,95,99$ per cent level (two-tailed test)

of openness for highly developed economies.

On the right hand side of table 1 (columns $1 b-4 b$ ), the results for corpshare 
(corporate tax revenues as a percentage of GDP) as endogenous variable are presented. In line with the studies by Quinn, Garrett and Swank, it is seen that globalization captured by open has a positive impact on this measure of corporate taxation; the estimated parameter is significant in estimations $3 \mathrm{~b}-4 \mathrm{~b}$. openness is also positive in the same estimations but not significant. growth changes sign with the endogenous variable used by Quinn, which is not according to our theoretical approach. Moreover, the well-founded variable gov is not successful in this specification. To conclude, only a change of the dependent variable from corptax to corpshare changes the key result. I.e. introducing the new measure for capital taxes shows the negative impact as predicted by the tax competition theory. In addition, it seems that the result for the country dummies is somewhat more accurate for the corptax equations than for the corpshare specification.

\section{Conclusions}

According to our empirical results, globalization has a negative effect on capital tax rates. It can be shown that the opposite conclusion drawn in recent literature is mainly due to the use of a different, but, in our view, much less appropriate measurement of the decisive variable. Our results support the tax competition theory and hence the so-called "efficiency hypothesis" of globalization, which says that it is efficient for governments to decrease taxes on mobile factors relative to immobile factors. While it is conceivable that tax competition has a strong effect on the tax mix, the effect on total government expenditures is not yet determined. Because taxes on rather immobile factors such as labour yield a much higher revenue than taxes on corporate capital, it is still possible to offer individuals compensation for increasing individual risks in a globalized world, which is the socalled "compensation hypothesis". To do so, the government might use special social security programs, which are financed by raising labour or consumer taxes.

\section{Acknowledgements}

We thank Dennis Quinn and Thomas Cusack for generously giving us access to their data on the regulation of international financial transactions and indices measuring the centre of political gravity, respectively. 


\section{References}

Baldwin, R.E. (1992) Measurable Dynamic Gains from Trade. Journal of Political Economy, 100, 162-174.

Beck, N. and J.N. Katz (1995) What to do (and not to do) with Time-Series Cross-Section Data. American Political Science Review, 89, 634-647.

Bucovetsky, S. (1991). Asymmetric Tax Competition. Journal of Urban Economics 30, 167-181.

Bucovetsky, S. and J.D. Wilson (1991) Tax Competition with Two Tax Instruments. Regional Science and Urban Economics 21, 333-350.

Cusack, T.R (1997) Partisan Politics and Public Finance: Changes in Public Spending in the Industrialized Democracies 1955-1998. Public Choice 91, 375-395.

Dooley, M.P and M.D. Chinn (1997), Financial Repression and Capital Mobility: Why Capital Flows and Covered Interest Rate Differentials Fail to Measure Capital Market Integration, Bank of Japan, Monetary and Economic Studies, 15(4), 81-103. (also: NBER Working Paper No. W5347).

Garrett, G. (1995) Capital Mobility, Trade and the Domestic Politics of Economic Policy. International Organization 49(4), 657-687.

Garrett, G. (2000) Capital Mobility, Exchange Rates and Fiscal Policy in the Global Economy, Review of International Political Economy 7(1), 153-170.

Jones, C. (1995) R\&D-Based Models of Economic Growth, Journal of Political Economy, 103, 759-784.

Mendoza, E.G., A. Razin and L. Tesar (1994), Effective Tax Rates in Macroeconomics: Cross-Country Estimates of Tax Rates on Factor Income and Consumption, Journal of Monetary Economics 34, 297-323.

OECD (1999), OECD Statistical Compendium, National Accounts 1965-1996, Electronic Edition on CD Rom, edition 01/1999, Organisation for Economic Co-operation and Development, Paris.

Quinn, D. (1997) The Correlates of Change in International Financial Regulation, American Political Science Review 91(3), 531-551.

Rodrik, D. (1997) Trade, Social Insurance, and the Limits of Globalisation, NBER Working Paper 5905 (Cambridge).

Swank, D. (1998) Funding the Welfare State: Globalisation and the Taxation of Business in Advanced Market Economies, Political Studies XLVI, 671-692.

Wilson J.D. (1991) Tax Competition with Interregional Differences in Factor Endowments, Regional Science and Urban Economics 21, 423-451.

Zodrow G.R and P. Mieszkovsky (1986) Pigou, Tiebout, Property Taxation and the Underprovision of Local Public Goods, Journal of Urban Economics 19, 356-370. 


\begin{tabular}{|c|c|c|c|c|}
\hline \multicolumn{5}{|l|}{ Appendix } \\
\hline variable & description & source & mean & $\begin{array}{l}\text { standard } \\
\text { deviation }\end{array}$ \\
\hline \multicolumn{5}{|c|}{ endogenous } \\
\hline corptax & effective average corporate tax rate & author (2001) & 39.192 & 11.411 \\
\hline corpshare & corporate tax revenues as a per cnet of GDP & own calculations & 3.014 & 1.287 \\
\hline \multicolumn{5}{|l|}{ exogenous } \\
\hline growth & growth rate of GDP measured in PPP-US-dollars & own calculations & 2.912 & 2.391 \\
\hline size & $\begin{array}{l}\text { relative country size: } \\
\text { adj. GDP (country) / adj. GDP (average) }\end{array}$ & own calculations & 114.66 & 155.090 \\
\hline votigra & center of political gravity for electorate & Cusack (1997) & 3.038 & 0.270 \\
\hline legigra & center of political gravity for legislature & Cusack (1997) & 3.057 & 0.285 \\
\hline cabigra & center of political gravity for cabinet & Cusack (1997) & 3.15 & 0.698 \\
\hline gov & sum of votigra, legigra and cabigra & own calculations & 9.264 & 1.120 \\
\hline open & (imports + exports) / GDP & own calculations & 0.566 & 0.287 \\
\hline openness & restrictions on payment and receipts of capital & Quinn (1997) & 11.23 & 2.41 \\
\hline
\end{tabular}

If not specifically indicated, data for calculations are taken from OECD (1999). 